\title{
PRKDC wt Allele
}

National Cancer Institute

\section{Source}

National Cancer Institute. PRKDC wt Allele. NCI Thesaurus. Code C51004.

Human PRKDC wild-type allele is located in the vicinity of $8 q 11$ and is approximately 187 $\mathrm{kb}$ in length. This allele, which encodes PMS1 protein homolog 2 protein, may play a role in DNA double strand break repair and several other processes. 